\title{
APLIKASI TEKNOLOGI TEPAT GUNA MELALUI PEMANFAATAN ENERGI TERBARUKAN UNTUK PENERANGAN DAN PENGEMBANGAN WISATA WATU TEKEK KULONPROGO
}

\author{
Evrita Lusiana Utari ${ }^{1}$, Latifah Listyalina ${ }^{1}$, dan Novi Irawati ${ }^{2}$ \\ ${ }^{1}$ Universitas Respati Yogyakarta, \\ ${ }^{2}$ Sekolah Tinggi Pariwisata Ambarrukmo \\ E-mail: evrita_lusiana@yahoo.com
}

\begin{abstract}
ABSTRAK. Pemerintah daerah Kulonprogo memberdayakan potensi alam sebagai modal pembangunan dan pengembangan daerah. potensi wisata merupakan salah satu faktor pendukung dalam peningkatan lapangan pekerjaan, peningkatan pendapatan, dan perkembangan usaha kecil. Wilayah yang memiliki potensi wisata yang cukup besar salah satunya adalah Provinsi Daerah Istimewa Yogyakarta. Salah satu wilayah yang memiliki potensi wisata, yaitu wisata Watu Tekek di daerah Kabupaten Kulonprogo. Permasalahan yang timbul adanya keterbatasan energi listrik dalam memenuhi kebutuhan energi dikawasan wisata Watu Tekek dikarenakan lokasi wisata yang cukup curam dan medan yang terjal, belum adanya penataan dan pengembangan kawasan wisata Watu Tekek dan masih terbatasnya amenitas/fasilitas pendukung dan sarana prasarana dikawasan wisata Watu Tekek. Dengan program kemitraan masyarakat (PKM) dana hibah dari Kemenristekdikti memberikan solusi dari permasalahan tersebut dengan memenuhi kebutuhan energi listrik dengan menggunakan tenaga matahari berupa lampu penerangan, lampu hias, dan air mancur. Sedangkan untuk penambahan fasilitas pariwisata berupa penambahan gazebo, kursi taman , penambahan ornament tanah liat dan penataan taman. Metode kegiatan yang dilakukan dengan melaksanakan diskusi dan observasi, sosialisasi dan penyuluhan, melaksanakan pelatihan, perancangan alat dan pemasangan alat. Hasil luaran dari kegiatan ini berupa produk teknologi tepat guna berupa lampu bertenaga solar panel, produk gerabah, kursi, dan gazebo untuk penambahan fasilitas pedukung, dan memberikan informasi kepada masyarakat luas melalui media massa.
\end{abstract}

Kata kunci: Solar Panel; Teknologi Tepat Guna; Watu Tekek

\section{APPLICATION OF TECHNOLOGY IS APPROPRIATE THROUGH THE USE OF RENEWABLE ENERGY FOR LIGHTING AND DEVELOPMENT OF TOURISM WATU TEKEK KULONPROGO}

\begin{abstract}
ABSTRAK. The local government of Kulonprogo empowers the potential of nature as regional development and development capital. tourism potential is one of the supporting factors in increasing employment, increasing income, and developing small businesses. The region that has considerable tourism potential, one of which is the Special Province of Yogyakarta. One of the regions that has tourism potential, namely Watu Tekek tourism in the Kulonprogo Regency area. Problems arising from the limitations of electrical energy in meeting the energy needs of Watu Tekek tourism area due to quite steep tourist sites and steep terrain, the absence of structuring and development of Watu Tekek tourist area and limited facilities / supporting facilities and infrastructure in the tourist area of Watu Tekek. With the community partnership program (PKM), grant funds from the Ministry of Research, Technology and Higher Education provide solutions to these problems by meeting the energy needs of electricity using solar energy in the form of lighting, decorative lights and fountains. As for the addition of tourism facilities in the form of adding gazebos, garden chairs, addition of clay ornament and garden arrangement. Methods of activities carried out by carrying out discussions and observations, socialization and counseling, conducting training, designing tools and installing tools. The output of this activity is in the form of appropriate technology products in the form of solar-powered lamps, earthenware products, chairs, and gazebos for the addition of supporting facilities, and providing information to the general public through mass media.
\end{abstract}

Key words: Appropriate Technology; Solar Cell; Watu Tekek;

\section{PENDAHULUAN}

Kebijakan otonomi menuntut pemerintah daerah untuk memberdayakan potensi alam sebagai modal pembangunan. Potensi wisata dari lingkup kota, kabupaten, hingga yang terkecil yaitu desa, mulai dipasarkan demi meningkatkan lapangan kerja, meningkatkan pendapatan, serta mendukung perkembangan usaha kecil di daerah masing-masing. Wilayah yang memiliki potensi wisata yang cukup besar salah satunya adalah Propinsi Daerah Istimewa Yogyakarta. Salah satu wilayah yang memiliki potensi wisata yaitu wilayah Desa Sidoharjo yang memiliki luas area 1.350 hektar dengan luasan tersebut Desa Sidoharjo terbagi atas 18 Pedukuhan yang masingmasing dipimpin oleh seorang dukuh. Lokasi Watu Tekek berada di wilayah administratif Kabupaten Kulonprogo yang berjarak $\pm 40 \mathrm{~km}$ dari pusat kota. (Artikel, Masbei). Wilayah Desa Sidoharjo memiliki obyek Wisata yaitu wisata Watu Tekek ini menyuguhkan pemandangan hijau dan asri. Seperti halnya wisata kalibiru yang juga berada di Perbukitan Menoreh ini, Watu Tekek juga menyajikan suasana yang menyejukkan dan menenteramkan. Di kawasan ini masih banyak terdapat perkebunan teh dan juga perkebunan kopi. Hal inilah yang menjadikan usaha masyarakat setempat.

Dikawasan Watu Tekek memiliki beberapa usaha dan produksi yaitu Kopi Menoreh dan Jam Kayu. Dimana usaha ini sudah go international dan telah dikenal dimasyarakat luas. Obyek wisata Watu Tekek memiliki tingkat perekonomian yang produktif hal ini ditunjukkan adanya produk kopi menorah dan jam kayu. Namun ada satu obyek wisata yang juga menjadi 
tumpuan perekonomonian yaitu Wisata Watu Tekek yang masih kekurangan fasilitas. Fasilitas umum yang belum memadai yaitu penerangan ditempat Wisata Watu Tekek memunculkan gagasan untuk memberikan aplikasi teknologi tepat guna melalui pemanfaatan potensi energi terbarukan sebagai penerangan dan pengembangan kawasan wisata Watu Tekek. Produk yang dihasilkan dari pemanfaatan energi matahari tersebut nantinya, dapat digunakan untuk penerangan, guna menambah daya Tarik wisata di kawasan wisata Watu Tekek dapat dilihat pada Gambar 1.

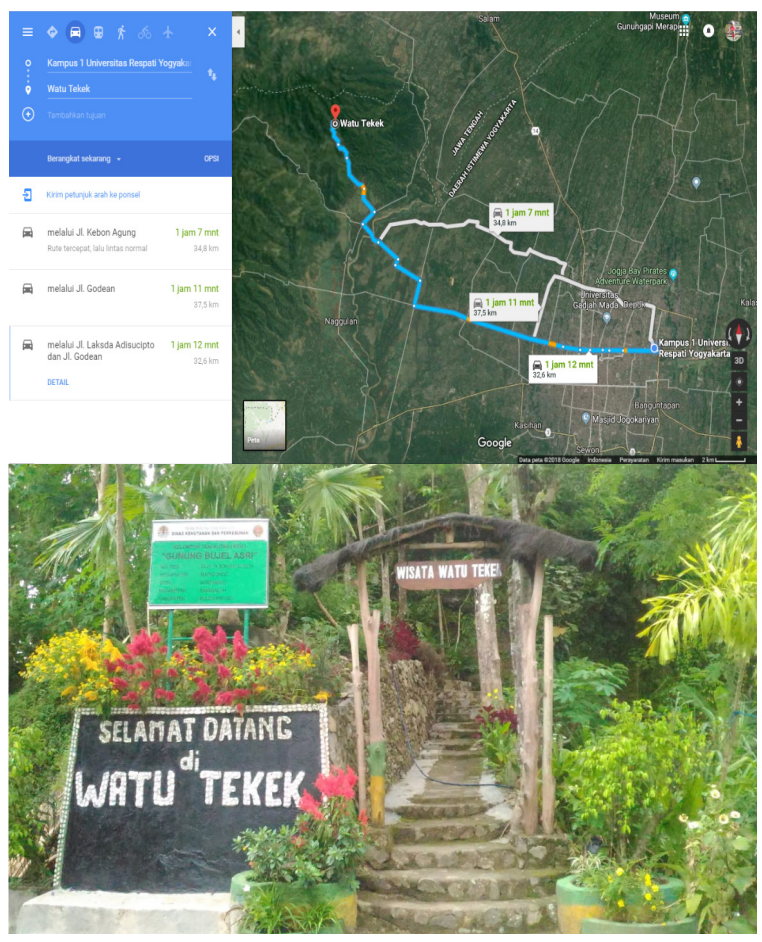

Gambar 1. Peta dan Lokasi Watu Tekek

Di Kawasan Wisata Watu Tekek terdapat UMKM yang berperan dalam mengkoordinasikan berbagai kegiatan pengembangan wisata yang dikenal dengan nama Kelompok Tani Hutan Gunung Bujel Asri. Kelompok Tani tersebut di ketua oleh Bapak Mashuri. Kelompok Tani Hutan ini bergerak dibidang pariwisata dengan pemberdayaan Wisata Hutan didaerah Watu Tekek Samigaluh, Kulon Progo. Kekuatan identitas kawasan di wilayah Sidoharjo itulah yang menjadi dasar atau landasan dalam memperkuat fasilitas yang sangat dibutuhkan masyarakat di daerah tersebut. Adapun energi yang dibutuhkan menggunakan Pembangkit Listrik Tenaga Surya (PLTS). PLTS ini adalah metode yang relatif baru dalam pembangkitan energi listrik dengan memanfaatkan energi matahari. Sistem Pembangkit Listrik Tenaga Surya (PLTS) sebagai pembangkit listrik diarahkan agar dapat dimanfaatkan oleh para pemakai yang tidak dijangkau oleh PLN [1][4] (Timotus dkk, 2009). Dengan produk teknologi ini dapat diterapkan di tempat wisata Watu Desa Sidoharjo yang listriknya masih kurang agar dapat menambah daya tarik wisatawan yang berkunjung pada malam hari. Sehingga dapat menambah pendapatan warga disekitar tempat wisata tersebut. PLTS juga sangat mudah dalam instalasinya, sehingga mitra akan dapat memelihara peralatan ini dengan mudah. Dalam pemanfaatan energi alternatif pengganti listrik yang pernah dilaksanakan di Dusun Nglinggo untuk memenuhi kebutuhan penerangan jalan didaerah wisata Kebun Teh. Sistem PLTS terdiri dari panel surya, rangkaian pengatur pengisian, penyimpan energi listrik, inverter, pengkabelan serta konektor, dan perlengkapan mekanis lainnya [6] (Utari dkk, 2017). Perkembangan teknologi dari tiap-tiap komponen ini telah mampu menghasilkan sistem PLTS yang ekonomis dan handal. Industri nasional sudah mampu memproduksi hampir semua subsistem dari PLTS kecuali panel surya [2] (Kumara, 2010). Hal ini juga akan memacu perkembangan industri PLTS di Indonesia. Dalam aplikasi pada perencanaan system penerangan jalan umum dan taman di areal kampus USU dengan menggunakan teknologi tenaga surya yang di aplikasikan di area pendopo dan lapangan parkir [3] (Sihombing dkk, 2013). Dalam Analisa Strategi Pengelolaan Taman Nasional Gede Pangrango (TNGP) Untuk Pengembangan Pariwisata Alam Di Kawasan Hutan oleh Epi Syahadat. Ada beberapa aspek yang harus diperhatikan dalam pengembangan pariwisata alam, yaitu : pariwisata nasional, perencanaan kawasan, pengelolaan lingkungan, sosial ekonomi dan budaya, penataan ruang serta peraturan perundangan. Adapun strategi pengembangan Obyek dan Daya Tarik Wisata Alam meliputi pengembangan : aspek perencanaan pembangunan, aspek kelembagaan, aspek sarana dan prasarana, aspek pengelolaan, aspek pengusahaan, aspek pemasaran, aspek peran serta masyarakat dan penelitian dan pengembangan. Menurut Sylva lestari yang mengambil penelitian terakit pengembangan ekosistem di hutan lindung resgister 25 pematang tanggang kabupaten Tanggamus menggunakan Metode yang digunakan adalah obervasi, wawancara serta dokumentasi. Pengambilan data lapangan dilakukan pada Bulan Desember 2015 dengan mencatat lokasi potensi wisata menggunakan GPS, pengambilan dokumen objek-objek lansekap yang dipandang menarik kemudian diujicobakan kepada kalangan masyarakat yaitu masyarakat di lokasi penelitian dan wisatawan yang berkunjung ke Pantai Pahawang, dokumentasi serta wawancara.

\section{Permasalahan Mitra}

Berdasarkan analisis situasi tersebut muncul permasalahan bahwa masyarakat daerah wisata Watu Tekek, Kecamatan Samigaluh Kabupaten Kulon Progo Yogyakarta memiliki beberapa permasalahan yaitu:

1. Adanya keterbatasan energi listrik dalam memenuhi kebutuhan energi di Desa Sidoharjo utamanya 
dikawasan Wisata Watu Tekek. Hal ini terlihat dari beberapa wilayah tersebut masih belum ada aliran listrik dari PLN. Aliran listrik yang belum memadai dikarenakan lokasi wisata yang cukup curam dan medan yang terjal. Kondisi geografis inilah yang menjadikan permasalahan tersebut muncul.

2. Belum adanya penataan dan pengembangan Kawasan Wisata Watu Tekek.

3. Adanya keterbatasan amenitas/fasilitas pendukung dan sarana prasarana dikawasan wisata Watu Tekek.

4. Kurang pemahaman terkait dengan pemanfaatan energi baru dan terbarukan di wisata Watu Tekek, Desa Sidoharjo, Kecamatan Samigaluh, Kabupaten Kulon Progo.

5. Belum adanya produk dari energi baru dan terbarukan di wilayah Watu Tekek.

\section{Solusi Permasalahan Mitra}

Berdasarkan analisis situasi tersebut muncul permasalahan bahwa masyarakat daerah wisata Watu Tekek, Kecamatan Samigaluh Kabupaten Kulonprogo Yogyakarta memiliki beberapa permasalahan yang akan di berikan solusinya, yaitu:

1. Adanya keterbatasan energi listrik dalam memenuhi kebutuhan energi di Desa Sidoharjo utamanya dikawasan Wisata Watu Tekek. Hal ini terlihat dari beberapa wilayah tersebut masih belum ada aliran listrik dari PLN. Aliran listrik yang belum memadai dikarenakan lokasi wisata yang cukup curam dan medan yang terjal. Kondisi geografis inilah yang menjadikan permasalahan tersebut muncul. Oleh karena itu diperlukan energi lain selain listrik untuk memenuhi keterbatasan energi listrik tersebut. Dengan potensi energi baru melalui sinar matahari inilah dapat menjadikan sumber energi alternatif sebagai penerangan di tempat wisata tersebut. Luaran berupa Produk TTG, Video Kegiatan, Publikasi Artikel ilmiah dan media masa.

2. Belum adanya penataan dan pengembangan Kawasan wisata Watu Tekek. Sehingga perlu adanya penataan kembali agar dapat menambah daya Tarik wisatawan. Luaran berupa peningkatan pengetahuan masyarakat, video kegiatan, produk, publikasi artikel ilmiah dan media masa.

3. Adanya keterbatasan amenitas/ fasilitas pendukung dan sarana prasrana di kawasan wisata Watu Tekek. Oleh karena itu perlu adanya tambahan fasilitas pendukung wista agar dapat menambah wisatawan untuk ber-kunjung. Luaran kegiatan berupa produk, video kegiat-an, publikasi ilmiah dan media masa.

4. Belum adanya produk energi baru dan terbarukan di wilayah Watu Tekek. Oleh karena itu perlu adanya produk yang memanfaatkan aplikasi teknologi tepat guna menggunakan energi terbarukan. Aplikasi ini nantinya akan diterapkan untuk penerangan didaerah wisataWatu Tekek yang masih belum terjangkau listrik.
Faktor penerangan inilah yang menjadi skala prioritas didaerah wisata tersebut. Luaran berupa produk, video kegiatan dan publikasi artikel ilmiah dan media masa.

\section{METODE}

Metode Diskusi dan Observasi. Kegiatan PKM ini diawali proses pelaksanaan perijinan dimulai awal pengajuan proposal yang dilaksanakan pada bulan juli 2018. Proses ini dilakukan dengan melakukan komunikasi dengan Bapak Camat di Kecamatan Samigaluh. Dari informasi yang diperoleh dari Bapak Camat bahwa di daerah kecamatan Samigaluh masih ada tempat yang belum terjangkau oleh listrik yaitu di Desa Sidoharjo dikarenakan lokasi yang sangat sulit dan medan yang cukup terjal. Dari informasi inilah tim memohon ijin kepada Bapak Camat untuk melaksanakan program kemitraan masyarakat tahun 2019. Dari Bapak camat memberikan ijin kepada tim pelaksana untuk dapat melaksanakan program kemitraan masyarakat dengan menerjunkan tim pendamping dilapangan untuk dapat peninjauan langsung lokasi.

Metode Sosialisasi dan Penyuluhan. Memberikan sosialisasi kegiatan program kemitraan masyarakat (PKM). Sosialisasi kegiatan PKM dilaksanakan di Desa Sidoharjo Samigaluh Kulonprogo.Sosialisasi kegiatan ini menjelaskan tentang tahapan-tahapan kegiatan yang akan dilaksanakan di Desa Sidoharjo. Memberikan penyuluhan terkait dengan pemanfaaan teknologi tepat guna untuk penerangan dengan menggunakan energi matahari sebagai salah satu alternatif untuk penerangan di wisata Watu Tekek Samigaluh Kulon Progo dan Pengembangan kawasan wisata di Wisata Watu Tekek.

Metode Pelatihan. Kegiatan pelatihan merupakan kegiatan lanjutan yang dilakukan oleh pelaksana PKM terhadap kegiatan ceramah dan diskusi yang telah dilakukan. Kegiatan pelatihan ini meliputi pelatihan melakukan pengenalan peralatan dan bahan yang akan digunakan dalam perancangan produk. Dan pelatihan pengembangan dan perawatan Kawasan wisata.

Metode Perancangan Produk. Metode perancangan produk ini meliputi proses penyiapan bahan, perakitan alat, pengeboran alat, pengecoran tiang hingga pemasangan alat

Metode Publikasi dan Capain Luaran Kegiatan. Metode publikasi dalam bentuk jurnal ilmiah, publikasi media massa. Sedangkan untuk capaian luaran kegiatan selain publikasi juga ada video kegiatan, pemberdayaan masyarakat sekitar, teknologi tepat guna dan HAKI.

\section{HASIL DAN PEMBAHASAN}

Pelaksanaan diskusi dan observasi mendapatkan informasi terkait dengan keadaan wisata Watu Tekek baik dari penerangan maupun fasilitas pendukung wisata yang masih terbatas.

Pada proses sosialisasi dan penyuluhan yang dilakukan terkait dengan ke utuhan energi listrik yang akan digantikan dengan energi terbarukan ini 
mendapatkan antusias dari warga Watu Tekek. Hasil dari penyuluhan ini masyarakat dapat menerima kegiatan pengabdian yang akan dilakukan. Dan proses pemberdayaan masyarakat dilakukan dengan cara keikutsertaan masyarakat dalam kegiatan pengabdian masyarakat. Hasil dari kegiatan pelatihan masyarakat dapat melakukan perakitan dan pemasangan alat. Terutama dalam pemeliharaan alat setelah produk diberikan kepada masyarakat.

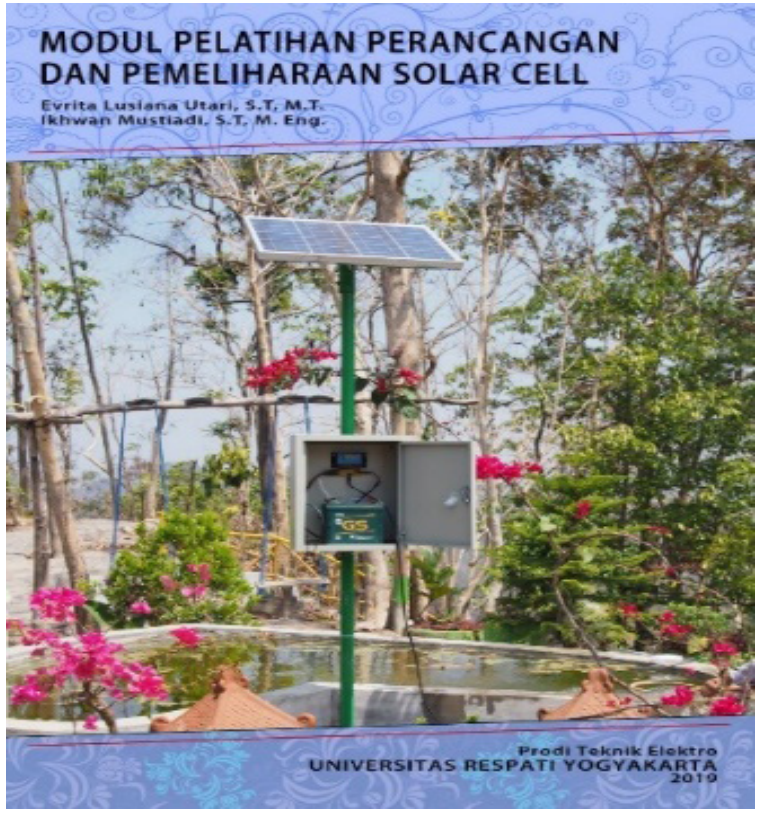

Gambar 2. Modul Pelatihan

Hail dari perancangan produk berupa produk penerangan yang terdiri dari Box Panel, Solar Charge Controler, Aki, Lampu dan produk Solar Panel untuk air mancur. Produk ini merupakan aplikasi teknologi tepat guna untuk penerangan dan air mancur dengan memanfaatkan energi matahari Sedangkan untuk penambahan amenitas atau pendukung fasilitas wisata berupa dari gerabah, kursi dan gazebo.

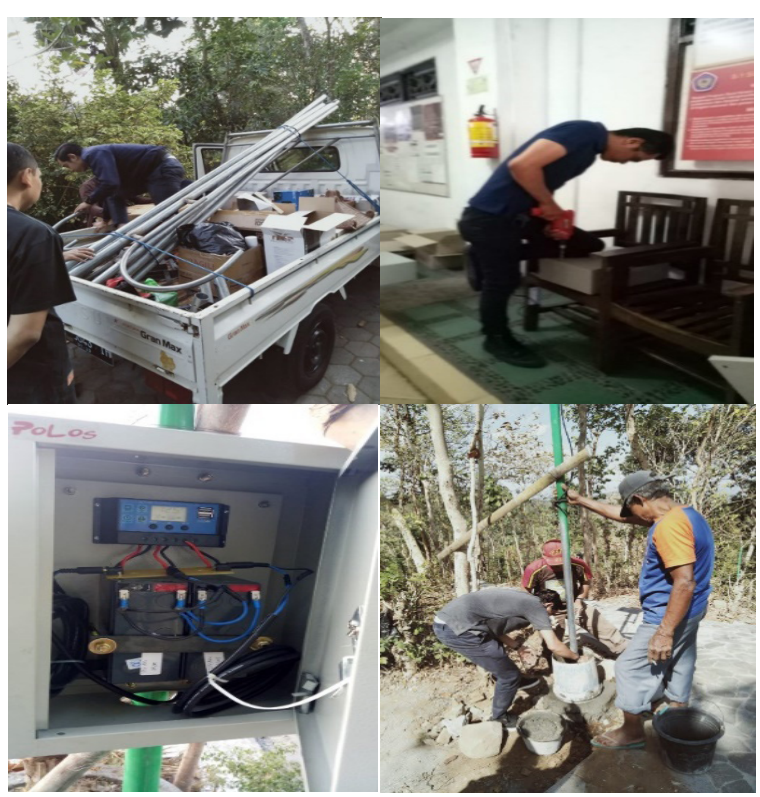

Gambar 3. Proses Perancangan Produk
Hasil dari publikasi ini berupa jurnal ilmiah, media massa yang telah terbit baik Cetak Jawa Pos-Radar Jogja Terbit Senin 22 Juli 2019 dan Harian Kedaulatan Rakyat Terbit Minggu, 21 Juli 2019 serta Media Online https:// radarjogja.co/2019/07/22/solar-panel-untuk-watutekek/. Untuk video kegiatan telah di upload di youtube, sedangkan pemberdayaan masyarakat berupa pembuatan Produk Gazebo dan Kursi Cor. Selain itu juga adanya penerapan teknologi tepat guna berupa produk dan HAKI berupa Hak Cipta Modul Pelatihan Perancangan dan Pemeliharaan Solar Cell.

\section{SIMPULAN}

Keterbatasan energi listrik dalam memenuhi kebutuhan energi di Desa Sidoharjo utamanya dikawasan Wisata Watu Tekek. Hal ini terlihat dari beberapa wilayah tersebut masih belum ada aliran listrik dari PLN. Aliran listrik yang belum memadai dikarenakan lokasi wisata yang cukup curam dan medan yang terjal. Kondisi geografis inilah yang menjadikan permasalahan tersebut muncul. Oleh karena itu diperlukan energi lain selain listrik untuk memenuhi keterbatasan energi listrik tersebut. Dengan potensi energi baru melalui sinar matahari inilah dapat menjadikan sumber energi alternatif sebagai penerangan di tempat wisata tersebut; Penataan kembali kawasan wisata dengan melakukan pengembangan dan penambahan fasilitas pendukung berupa pembetulan gazebo, penambahan kursi, penambahan tanaman hias agar dapat menambah daya Tarik wisatawan; Produk energi baru dan terbarukan di wilayah Watu Tekek dimanfaatkan dengan menerapkan aplikasi teknologi tepat guna menggunakan energi terbarukan. Aplikasi ini diterapkan pada penerangan didaerah wisata Watu Tekek, pada lampu hias, pada motor DC sebagai penggerak air mancur.

\section{UCAPAN TERIMA KASIH}

Terimakasih kamiucapkan kepada Kemenristekdikti yang telah memberikan dana hibah pengabdian masyarakat skim PKM ini, PPPM UNRIYO yang telah memfasilitasi pelaksananan pengabdian masyarakat, kepada Camat Samigaluh, Kepala Desa Sidoharjo, seluruh warga masyarakat Tim Watu Tekek yang telah membantu terlaksananya PKM beserta Tim pengabdian masyarakat Prodi Teknik Elektro UNRIYO.

\section{DAFTAR PUSTAKA}

Sihombing D.T.B, Kasim S.T 2013. Perencanaan Sistem Penerangan Jalan Umum dan Taman di Areal Kampus USU dengan Menggunakan Teknologi Tenaga Surya (Aplikasi di Areal Pendopo dan Lapangan Parkir Vol 3 No 3, SINGUDA ELSIKOM.

Timotus C, Ratnata W.I, Mulyadi Y, Mulyana E,2009. Perancangan dan Pembangkit Listrik Tenaga Surya, Laporan Hibah Penelitian Kompetitif, Bandung. 
Bachtiar M, 2006. Prosedur Perancangan Pembangkit listrik Tenaga Surya Untuk Perumahan (Solar Home System), Jurnal Smartek.

Kumara N, 2010. Pembangkit Listrik Tenaga Surya Skala Rumah Tangga Urban dan Ketersediaannya di Indonesia, Jurnal Teknik Elektro. Universitas Udayana Bali
Utari, EL, 2018. Pemanfaatan Energi Surya sebagai Energi Alternatif Pengganti Listrik untuk memenuhi Kebutuhan Penerangan Jalan di Dusun Nglinggo Kelurahan Pagerharjo Kecamatan Samigaluh Kabupaten Kulon Progo, Jurnal Dharma Bakti, Yogyakarta. 